\title{
Intraocular penetration of cephaloridine
}

\author{
*A. B. RIGHARDS, *A. J. BRON, *N. S. G. RIGE, *P. FELLS, \\ $\dagger$ M. J. MARSHALL, AND *B. R. JONES \\ From the *Professorial Unit, Moorfields Eye Hospital, London, and †Glaxo Laboratories Ltd., \\ Greenford, Middlesex
}

Cephaloridine ('Ceporin') is a semisynthetic compound, 7- [(2-thienyl)-acetamide]-5( I-pyridylmethyl) - 5-cephem-4-carboxylic acid betaine, derived from cephalosporin C. This is an antibiotic produced by Cephalosporium acremonium, a fungus isolated from a sewage outfall off the Sardinian coast (Brotzu, 1948).

The cephalosporins are closely related chemically to the penicillins in that they contain a $\beta$-lactam ring. This is the part of the molecule which almost certainly combines irreversibly with the binding sites on sensitive bacteria. Whereas penicillins contain a fivemembered thiazolidine ring, the cephalosporins have a six-membered dihydrothiazine ring (Fig. I).<smiles>[R]N[C@@H]1C(=O)N2SC(C)(C)[C@@H](C(=O)O)[C@@H]12</smiles>

Penicillin Nucleus

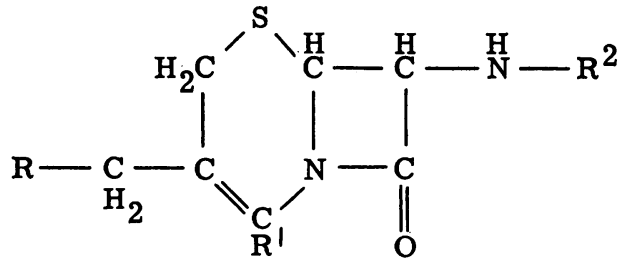

Cephalosporin Nucleus

Although cephalosporin $\mathrm{G}$ has only modest antibacterial properties, chemical substitution of various synthetic side-chains at the 7 amion group and the $\mathrm{C}_{5}$ position has resulted in the formation of highly effective and useful antibiotics, of which cephaloridine, cephalexin, and cephalothin are currently available for clinical use.

Cephaloridine is a broad-spectrum bactericidal antibiotic active in vitro against a large number of Gram-positive and Gram-negative bacteria (Table I, overleaf), including penicillin resistant strains of Staphyloccocus aureus, at minimum inhibitory concentrations of up to I $\mu \mathrm{g} . / \mathrm{ml}$. (Muggleton and O'Callaghan, I967; Murdoch, Speirs, Geddes, and Wallace, ig64).

The penicillins and cephalosporins act by irreversibly inhibiting an enzyme involved in the final stages of synthesis of the bacterial cell wall. Bacterial resistance to the action of these antibodies may be due either to their failure to reach or combine with the sensitive sites on the bacterial cell, or to their destruction by $\beta$-lactamase (or 'penicillinase') produced by the organisms. The formation of the enzyme may be a constitutional property of the organisms or it may be induced by antibiotics. $\beta$-lactamases have proved an especially serious problem in relation to Staph. aureus. The presence of the dihydrothiazine ring in the cephalosporins, however, makes these drugs highly resistant to the action of staphylococcal $\beta$-lactamase (Newton and Hamilton-Miller, I967). 
Table I Bacterial sensitivity to cephaloridine in vitro based on minimum inhibitory concentration

After Muggleton and O'Callaghan, 1967

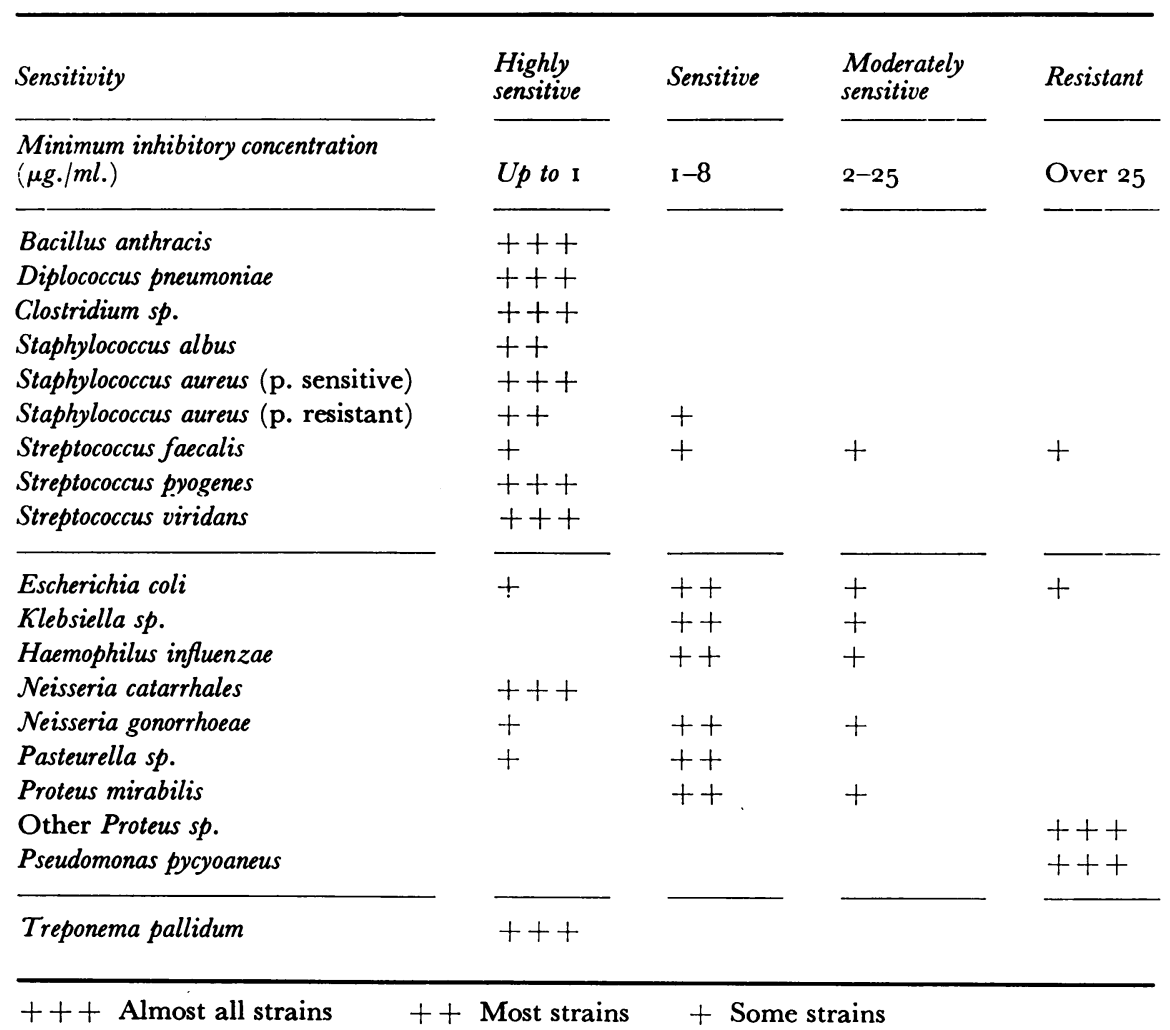

The penicillins may cause severe allergic reactions in some individuals. It might beo expected because of similarities in structure, that there would be some cross-allergenicity. between these drugs and the cephalosporins. This probably does occur rarely. Clinica解 experience has shown, however, that cephalosporins can be given with safety in most patients known to be allergic to penicillin if administered with caution (Editorial, 1964 Newton and Hamilton-Miller, 1967; Stewart, 1967; Pines, Raafat, Plucinski, Greenfield, and Linsell, 1967; Riley, Boyle, and Leopold, I966; Records, r968, I969a, b).

Cephaloridine is poorly absorbed from the gastrointestinal tract and must be given by injection. Single intramuscular injections in man of 0.25 to $2 \mathrm{~g}$. yield peak serum concentrations at $\mathrm{I}$ to 2 hours of 5 to $45 \mu \mathrm{g}$./ml. which are proportional to dose. With adequate dosage, serum concentrations above the minimum inhibitory concentration for many bacteria may be maintained for at least 6 hours.

At least 80 per cent. of an injected dose of cephaloridine appears unchanged in the urine of healthy subjects during the first 24 hours. This is mostly excreted in the first 6 hours by glomerular filtration (Currie, 1967). Cephaloridine, unlike cephalothin, shows a low degree of protein binding. Both cephalothin and cephalexin have a moderate tubular $\frac{\mathrm{O}}{\mathrm{P}}$ excretory component so that levels may be prolonged and a higher peak produced by including probenecid in the treatment schedule. 
Transient signs of renal toxicity may occur when over $6 \mathrm{~g}$. cephaloridine are given daily and caution is suggested at this dosage (Pines and others, 1967 ). Other adverse reactions including skin rashes have been recorded (Foord, I967; Records I969a,b).

\section{Ophthalmological studies}

Riley and others (1968) found therapeutic levels of cephaloridine in primary aqueous after the intramuscular injection of $\mathrm{I} g$. in man. Peak serum and aqueous levels were reached at $\mathrm{I}$ hour and 3 to 4 hours respectively after injection.

Records found no penetration of cephaloridine into the primary aqueous of rabbits after a $15 \mathrm{mg} . / \mathrm{kg}$. intravenous injection. Small therapeutic levels were achieved in secondary aqueous using the same dose in rabbits or a I g. dose in man (Records, I968). With a dose of I $\mathrm{g}$. cephaloridine intravenously, a high concentration of the drug was achieved in human secondary aqueous (Records I969a, b). Mean aqueous levels of $28 \cdot 4$ and $25.2 \mu \mathrm{g} . / \mathrm{ml}$. were achieved $\mathrm{I}$ and 2 hours respectively after injection. The highest aqueous level in this study was $65.0 \mu \mathrm{g} . / \mathrm{ml}$. and the highest serum level $500 \mu \mathrm{g} . / \mathrm{ml}$. Mizukawa, Azuma, and Kawaguchi (1965) and Hatano, Kayaba, and Shiga 1966) confirmed the superior intraocular penetration of cephaloridine in comparison to cephalothin.

Subconjunctival injection of $50 \mathrm{mg}$. of either of these drugs produces high aqueous titres. Cephaloridine has been used clinically by this route. (Records, I968, I969a, b; Ikui, Oniki, and Nonaka, I966). Rosa (1967) used cephaloridine topically at a concentration of 4 per cent. in the treatment of ocular infection.

\section{Current study}

\section{MATERIAL AND METHODS}

29 samples of blood and aqueous were assayed for levels of cephaloridine. 26 patients underwent routine cataract extraction. One (No. I I) had Fuchs's heterochromic cyclitis. Three examples (Nos 18, 29, 30) were from two patients with herpes simplex kerato-uveitis being treated by anterior chamber washout, one of whom underwent two separate anterior chamber washouts on different occasions. Three of the routine cataract patients received no preoperative antibiotics and acted as controls; no antibiotic was demonstrable in their samples. All of the other patients in the study received $30 \mathrm{mg}$. cephaloridine per $\mathrm{kg}$. body weight by intramuscular injection into the buttock, between $\mathrm{I}$ and 4 hours preoperatively (Table II, overleaf). Before the main operation the aqueous was aspirated through a paracentesis wound and a simultaneous blood sample was obtained; the technique employed was modified from that of Jones, Patterson, and Rice (1968). The chamber was reformed with Ringer saline before proceeding with surgery. A further blood sample was collected approximately 2 hours later; blood was allowed to clot and serum was separated by centrifugation and stored at $-40^{\circ} \mathrm{C}$. Aqueous samples were transferred to weighed plastic microcentrifuge tubes at $-40^{\circ} \mathrm{C}$.

Cephaloridine assays of serum and aqueous were carried out by the agar diffusion method, using Bacillus subtilis $84 \mathrm{I}$ as the assay organism.

\section{RESULTS}

Results of the assays of samples taken at the time of operation are given in Table II and are shown on the graphs in Fig. 2( overleaf), which include the results of the later serum samples.

It will be seen that a high aqueous level of cephaloridine was found in Patient I I, who had heterochromic cyclitis, and also in Patients 18, 29, and 30, who had kerato-uveitis, in 
Table II Dosage, time interval, and cephaloridine assay results

\begin{tabular}{|c|c|c|c|c|c|c|}
\hline $\begin{array}{l}\text { Study } \\
\text { number }\end{array}$ & Sex & $\begin{array}{c}\text { Age } \\
(y r s)\end{array}$ & $\begin{array}{l}\text { Dose } \\
(g .)\end{array}$ & $\begin{array}{l}\text { Time after } \\
\text { injection } \\
\text { (hrs. min.) }\end{array}$ & $\begin{array}{l}\text { Aqueous } \\
(\mathrm{mg} . / \mathrm{ml} .)\end{array}$ & $\begin{array}{l}\text { Serum } \\
(m g . / m l .)\end{array}$ \\
\hline $\mathbf{I}$ & $\mathbf{F}$ & 55 & 2 & $1 \cdot 40$ & - & $32 \cdot 5$ \\
\hline 2 & $\mathbf{M}$ & 59 & $\mathbf{I}$ & $1 \cdot 35$ & - & $67 \cdot 6$ \\
\hline 3 & $\mathbf{F}$ & 62 & I & $1 \cdot 5^{0}$ & $1 \cdot 3$ & $34 \cdot 5$ \\
\hline 4 & $\mathbf{M}$ & $4^{I}$ & 2 & $1 \cdot 35$ & 0.5 & $49^{\circ} 0$ \\
\hline 5 & $\mathbf{M}$ & 70 & $\mathrm{I} \cdot 8$ & $1 \cdot 30$ & $I \cdot I$ & $82 \cdot 6$ \\
\hline 6 & $\mathbf{F}$ & 74 & $2 \cdot 3$ & $2 \cdot 30$ & 0.8 & $33 \cdot 7$ \\
\hline 7 & $\mathbf{M}$ & 66 & $2 \cdot 6$ & $I \cdot 55$ & 0.7 & $55 \cdot 4$ \\
\hline 8 & $\mathbf{M}$ & 62 & $2 \cdot 6$ & $\mathrm{I} \cdot 55$ & 0.7 & $68 \cdot 0$ \\
\hline 9 & $\mathbf{M}$ & $5^{6}$ & $2 \cdot 5$ & $3 \cdot 00$ & $2 \cdot I$ & $37 \cdot 6$ \\
\hline 10 & $\mathbf{M}$ & 64 & $1 \cdot 6$ & $1 \cdot 45$ & $I \cdot O$ & $45 \cdot 2$ \\
\hline II & $\mathbf{F}$ & 47 & I $\cdot 9$ & $3 \cdot 30$ & $5 \cdot 4$ & $29 \cdot 6$ \\
\hline 12 & $\mathbf{F}$ & 65 & $2 \cdot 1$ & $\mathrm{I} \cdot 55$ & $I \cdot O$ & $45 \cdot 9$ \\
\hline 14 & $\mathbf{F}$ & 80 & $1 \cdot 4$ & $1 \cdot 30$ & $3 \cdot 7$ & $58 \cdot 7$ \\
\hline 15 & $\mathbf{F}$ & 69 & $I \cdot I$ & $1 \cdot 15$ & 0.8 & $36 \cdot 7$ \\
\hline 16 & $\mathbf{F}$ & 66 & $2 \cdot 1$ & $\mathrm{I} \cdot 55$ & $1 \cdot 8$ & $49 \cdot 2$ \\
\hline 17 & $\mathbf{M}$ & 65 & $2 \cdot 6$ & $\mathrm{I} \cdot 35$ & 0.75 & $4^{8 \cdot 9}$ \\
\hline 18 & $\mathbf{M}$ & $5^{I}$ & $\mathrm{I} \cdot 8$ & I $\cdot 05$ & 10.6 & - \\
\hline 20 & $\mathbf{M}$ & 23 & $2 \cdot 0$ & $3 \cdot 35$ & 0.9 & $18 \cdot 9$ \\
\hline 22 & $\mathbf{F}$ & $5^{1}$ & $\mathrm{I} \cdot 8$ & $1 \cdot 35$ & 0.4 & $3^{1 \cdot 1}$ \\
\hline 25 & $\mathbf{M}$ & 68 & $\mathrm{I} \cdot 9$ & $3 \cdot 25$ & $<0.4$ & $27 \cdot 3$ \\
\hline 27 & $\mathrm{~F}$ & 85 & $\mathbf{I} \cdot 8$ & 3.50 & $2 \cdot 3$ & $37 \cdot 1$ \\
\hline 28 & $\mathbf{F}$ & 76 & $2 \cdot 2$ & $3 \cdot 5^{6}$ & $3 \cdot 2$ & $30 \cdot 9$ \\
\hline 29 & $\mathbf{F}$ & 38 & I $\cdot 8$ & $1 \cdot 25$ & $9 \cdot 2$ & $38 \cdot 7$ \\
\hline 30 & $\mathbf{F}$ & 38 & $\mathrm{I} \cdot 8$ & $2 \cdot 30$ & $I I \cdot I$ & $30 \cdot 2$ \\
\hline $3^{1}$ & $\mathbf{F}$ & 71 & $2 \cdot 2$ & $I \cdot 45$ & 0.9 & $40 \cdot 3$ \\
\hline
\end{tabular}

whom even higher levels were discovered. In the routine cases, most aqueous samples contained therapeutically useful levels of cephaloridine. The peak levels in aqueous appear to occur some time after those in serum.

No untoward reactions were experienced by any of our patients and the injection was well tolerated.

\section{Discussion}

The present study shows, like that of Riley and others (1968), that adequate aqueouso levels of cephaloridine are achieved in the primary aqueous after intramuscular injection Excellent peak serum levels were achieved with the single dose employed of $30 \mathrm{mg} . / \mathrm{kg}$ Aqueous levels would be expected to rise as long as a positive diffusion gradient existed between plasma and aqueous. The value for serum and aqueous cephaloridine given ${ }^{\omega}$ in Fig. 4 suggests that in most cases peak levels would occur 6 hours or more after intramuscular injection. Thus the cluster of aqueous values under $2 \mu \mathrm{g} . / \mathrm{ml}$. in the I to $3 \frac{0}{\delta}$ hour period after injection, probably give a falsely low impression of the highest attainable $\stackrel{f}{?}$ antibiotic concentration on the single dose regime. Certainly, there is a suggestion from ${ }^{\circ}$ the graph that the primary aqueous levels are still rising at 4 hours.

If peak aqueous levels occur as late as suggested, then a further rise in levels would be anticipated on a divided dose regime, since aqueous levels would not fall to zero between successive doses. However, the dose of $30 \mathrm{mg} . / \mathrm{kg}$. used here, repeated on a $6-$ or 8- 


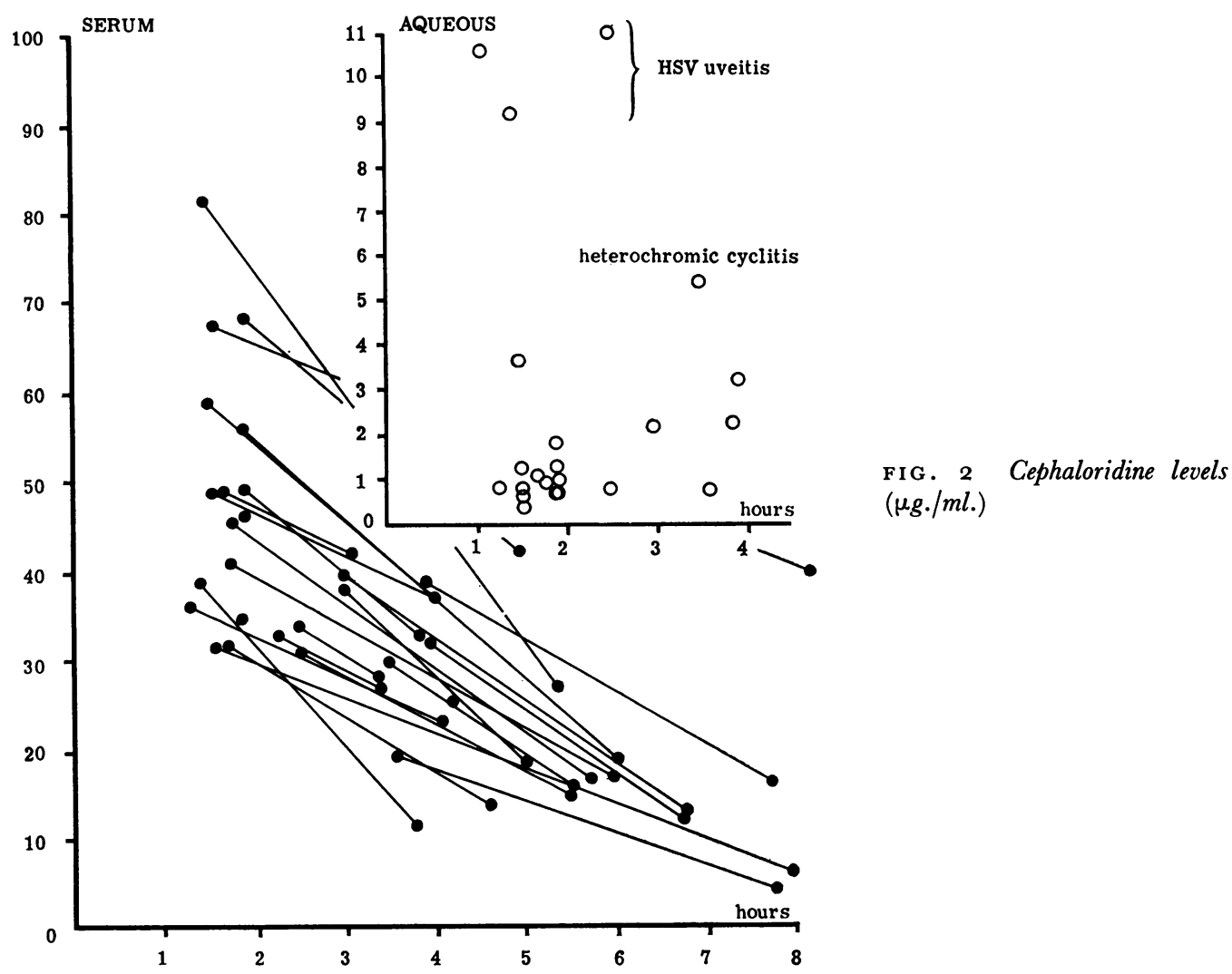

hourly schedule would be higher than that employed except in most severe infections. A $15 \mathrm{mg} . / \mathrm{kg}$. dose of cephaloridine would be more usual. Riley and others (1968) in fact found no definite rise in aqueous titre on a dose of I g. given 6- to 8-hourly.

It is of more than academic interest to know the attainable level of cephaloridine in primary aqueous after systemic administration. Cephaloridine is one of the small number of antibiotics known to be effective against Treponema pallidum, and a minimum inhibitory concentration of 0.5 to $1 \mu \mathrm{g} . / \mathrm{ml}$. is quoted for this drug (Flarer, 1967). The growing interest in the possibility that $T$. pallidum may survive in the eyes of syphilitic patients has posed the problem of how to deliver an effective drug to the organism in the clinically quiet eye. Cephaloridine may find use in this area as well as in the more general area of preoperative prophylaxis.

It is likely that systemic cephaloridine will be of greatest use to ophthalmologists in the treatment of fulminating ocular infection. The findings presented here confirm those of Records (1969a, b) that, in secondary aqueous or in the presence of anterior segment inflammation, the breakdown of the blood-aqueous barrier permits a readier diffusion of the drug from the plasma into the anterior chamber. The levels of cephaloridine of $9 \cdot 2$, I 0.6 , and I I $\mu \mathrm{g} . / \mathrm{ml}$. achieved in the presence of severe inflammation were far higher than those required to inhibit a wide range of micro-organisms. It would seem likely that higher levels would have been present had samples been taken at later times.

In selecting a member of the cephalosporin group of antibiotics to treat a bacterial infection of the eye, cephaloridine seems to be the drug of choice. Cephalothin is prob- 
ably more resistant to penicillinase than cephaloridine, but cephaloridine shows superior ocular penetration (Records, I969a, b; Mizukawa and others, r 965; Hatano and others, 1966) and gives less pain at the site of intramuscular injection.

Cephalexin, which is well absorbed after oral administration, also penetrates the eyes (Gager, Elsas, and Smith, 1969; Boyle, Hein, and Leopold, 1970), but it has a lowero bactericidal activity than the two other drugs.

\section{Summary and conclusion}

In the present study cephaloridine was given in a single dose of $30 \mathrm{mg} . / \mathrm{kg}$. by intramuscular $\vec{\circ}$ injection to patients about to undergo intraocular surgery. The drug entered primary aqueous in therapeutic concentrations. In a few subjects with anterior uveitis, particularlyo high aqueous levels of cephaloridine were achieved.

The drug is active against both Gram-negative and Gram-positive organisms, includinge penicillin resistant staphylococci. It may be used as an alternative to penicillin when there is a history of allergy. It is effective against Treponema pallidum. An intramuscularw dose of $15 \mathrm{mg}$. $/ \mathrm{kg}$. 8-hourly for a moderately severe ocular infection, and of $30 \mathrm{mg} . / \mathrm{kg}$. for a more severe infection, is recommended.

\section{References}

Boyle, G. L., Hein, H. F., and Leopold, I. H. (1970) Amer. J. Ophthal., 69, 868 Brotzu, G. ( I948) Labori del l'Institute d'Igene di Cagliari, 3 Currei, J. P. (1967) Postgrad. med. J., 43, August Suppl., p. 22. EDITORIAL (1964) Brit. med. J., 2, 12 I I

— (1967) J. Amer. med. Ass., rg9, 495

Flarer, F. (1967) Postgrad. med. 7., 43, August Suppl., p. 133

FOORD, R. D. (1967) Ibid., 43, August Suppl., p. 63.

GAGER, W. E., ElSAS, f. J., and SMith, J. LAWTON (1969) Brit. J. Ophthal., 53, 403

hatano, H., KAyabA, т., and shiga, N. (1966) Jap. J. clin. Ophthal., 20, 805

IKUI, H., ONIKI, S., and NONAKA, Y. (1966) Ibid., 20, I 339

JONES, B. R., PATterson, A., and RICE, N. s. C. (I968) Trans. ophthal. Soc. U.K., 88, 23.5

mizukawa, t., Azuma, i., and kaWaguchi, s. (1965) J. Antibiot. Ser. B (Japanese ed.), 18, 525

muggleton, P. W., and o'callaghan, c. H. (1967) Postgrad. med. J., 43, August Suppl., p. 17 MURDOGH, J. M., SPEIRS, G. F., Geddes, A. M., and WAllace, E. T. (I964) Brit. med. J., 2,1238 NEWTON, C. G. F., and hamilton-miller, J. M. T. (1967) Ibid., 43, August Suppl., p. Io Pines, A., RAAfat, H., Plucinski, K., Greenfield, J. S. B., and linsell, W. D. (I967)

Chest, 6r, $10 \mathrm{I}$

RECORDs, R. E. (1968) Amer. 7. Ophthal., 66, 436 and 4 I I

- (1969a) Arch. Ophthal., 8r, 33 I

- (1969b) Surv. Ophthal., r3, 345

RILEY, F. C., BOYLe, G. L., and LeOPOLD, I. H. (1968) Amer. J. Ophthal., 66, I042

ROSA, D. ( 1967 ) Minerva oftal., 9, I 77

stewart, G. T. (1967) Postgrad. med 7., 43, August Suppl., p. 3 I

WAshington, J. A., and yU, P. к. W. (1970) Appl. Microbiol., r9, 589 